\title{
STEM and STEAM Education in Russian Education: Conceptual Framework
}

\author{
Liudmila V. Shukshina ${ }^{1 *}$, Liudmila A. Gegel ${ }^{2}$, Maria A. Erofeeva ${ }^{3,4}$, Irina D. Levina ${ }^{5}$, \\ Uliana Y. Chugaeva ${ }^{6}$, Oleg D. Nikitin ${ }^{7}$ \\ ${ }^{1}$ Plekhanov Russian University of Economics, Moscow, RUSSIA \\ ${ }^{2}$ Moscow Aviation Institute (National Research University), Moscow, RUSSIA \\ ${ }^{3}$ Moscow University of the Ministry of Internal Affairs of Russia named after V.Ya. Kikot, Moscow, RUSSIA \\ ${ }^{4}$ State University of Humanities and Social Studies, Kolomna, RUSSIA \\ ${ }^{5}$ Moscow City University, Moscow, RUSSIA \\ ${ }^{6}$ I.M. Sechenov First Moscow State Medical University (Sechenov University), Moscow, RUSSIA \\ ${ }^{7}$ Peoples' Friendship University of Russia (RUDN-University), Moscow, RUSSIA
}

Received 1 April 2021 - Accepted 19 June 2021

\begin{abstract}
The paper examines the STEM approach as one of the revolutionary tools for transforming education. This paper discloses the content of the concept of "STEAM-education", substantiates its importance and prerequisites for its appearance. The author elucidates a comparative analytical review of trends and prospects for the development of STEAM education in the Russian Federation. In this paper, the authors want to touch upon a comprehensive theoretical and methodological study conducted on the declared problem to identify the problem of the formation and development of the STEAM approach in the education system in the Russian Federation at all levels: general education, vocational education, and additional education. The object of this study was STEM education. The subject of this research was the STEM approach and STEM technologies in the system of general education, vocational education, and additional education. The methodological foundation of the study was the general scientific propositions on the holistic, systemic, and dialectical approaches to research, which made it possible to assess the totality of interrelated and interacting elements that form a certain integrity. The use of these approaches provided a comprehensive analysis and formulation of the research problem and determined the strategy for its study. The analysis of the current state of STEM and STEAM education in higher education in the Russian Federation suggests that it is necessary to stimulate the development of information and communication technologies in the country's education system in general, as well as to develop comprehensive programs for adapting STEM and STEAM approaches among the subjects of educational relations. In the context of modern global risks and challenges, the educational trajectory of development in Russia should be conceptually consistent with the new strategy in the field of natural science education adopted in the United States, "The Path to Success: American Strategy for STEM Education". Experts believe that through the practical implementation of STEM and STEAM technologies, it is possible to improve the efficiency of the quality of training for the purposes of the modern digital economic sphere. In this regard, the primary competences obtained in the higher education system in the areas of STEM and STEAM training should be cognitive, personal, and interpersonal competences, expressed in digital literacy, computational thinking, creativity, open mind, soft skills, and others. The concept of STEAM education in the system of higher professional education in Russia will ensure the transformation of ideas about scientific knowledge and build an innovative development process through the formation of skills in the field of exact sciences, linguistics, engineering, art, etc.
\end{abstract}

Keywords: STEM, STEAM, higher education, teaching methodology, project form, universities, communication, integrated approach, innovation, engineering education

\section{INTRODUCTION}

Digitalization is rapidly penetrating all areas of our life. This trend has not passed the field of education by.
The main goal of the STEM approach is to overcome the isolation inherent in traditional education from solving practical problems and to build relations between university disciplines that are understandable for

(c) 2021 by the authors; licensee Modestum. This article is an open access article distributed under the terms and conditions of the Creative Commons Attribution License (http://creativecommons.org/licenses/by/4.0/). 


\section{Contribution to the literature}

- This study presents a comparative analytical review of trends and prospects for the development of STEAM education in the Russian Federation.

- This study provides a generalized system for formation and development of the STEAM approach in the education system in the Russian Federation at all levels: general education, vocational education, and additional education.

- This study proves that it is necessary to stimulate the development of information and communication technologies in the country's education system in general, as well as to develop comprehensive programs for adapting STEM and STEAM approaches among the subjects of educational relations.

- The results study proves that through the practical implementation of STEM and STEAM technologies, it is possible to improve the efficiency of the quality of training for the purposes of the modern digital economic sphere.

students. The idea and acronym STEM was first proposed by scientists at the US National Science Foundation in 2001 as a guide to the education modernization of contemporary engineers and researchers in universities. The idea was supported by the government, civil society organizations and several American companies. Thus, the fundamental principles of STEM began to be applied in the development of educational programs in a wide variety of higher education institutions in the United States.

Today, the American education system trains several hundred specialists in different engineering, as well as scientific from educational institutions according to programs, which have been designed in view of the concept of STEM. At the same time, the preparation of a master's thesis of students is combined with practical training in various technological enterprises and gives an opportunity to take part in various complex projects of a technological nature. As a result, tech companies hire trained professionals immediately after their graduation (Kalugina et al., 2018; Kvon et al., 2019; Loyalka et al., 2021; Salakhova et al., 2019, 2020; Semenova et al., 2019; Usak et al., 2020).

After the successful testing of the STEAM approach in educational institutions in the United States, the STEM approach began to be used in many countries around the world. Currently, STEM specialists are trained at universities around the world, both Western Europe and Asia, North America (Bahrum et al., 2017; Frolov et al., 2010; Sabirova \& Deryagin, 2018; Tugun et al., 2020).

In addition, it should be noted that after higher education, the elements of such a system began to spread actively, including in the system of general, as well as additional education.

Thus, the significance of the topic in conditions when the Russian Federation strives to become one of the most developed countries in the world is beyond any doubt. The education system in our country needs a comprehensive reform.

\section{THEORETICAL ANALYSIS}

It is expedient to examine the content of the term "STEM", as well as the components of this category.

In the twenty-first century, society strives to devise and master new technologies, there is a constant process of forming new professions, the demand for those specialties that are related to IT, engineering, big data analysis, linear programming and design is increasing. Against the background of all these changes, a new type or a new education system emerges - STEM.

STEM is an abbreviation that stands for Science, Technology, Engineering, Mathematics. STEM is a practice-oriented approach focused on the formation of a special educational content, as well as the organization of educational activities. STEM is an integrated approach that unites the listed disciplines (Akiri et al., 2021; Caplan, 2017).

It should be noted that the problem of the correctness of the scientific terminology definition is, of course, significant for any practical activity. There should be a certain approach, the author's paradigm, a system of views at the foundation of any proposed materials and methods. In this regard, it is necessary to carry out a strictly structured analysis of the definition of STEMapproach based on scientific methodology (Aleksankov, 2017; Frumin et al., 2018; Hymes, 1972; Kvachev \& Yudina, 2017; Nechitailo \& Makeyev, 2018).

The STEM approach is based on the following fundamental principles:

1) the educational process has a project form, which involves the unification of students around the joint solution of the educational tasks assigned to them;

2) educational tasks are practical in nature, and the final results can be used by the family, class, school, university, enterprise, city, etc.;

3) the interdisciplinary nature of training: educational tasks are structured in such a way that knowledge from several scientific areas should be used simultaneously;

4) discipline coverage is of key importance in the process of training engineers or experts in applied 
scientific research: subjects of the scientific cycle, advanced technologies, various disciplines of an engineering order, etc. (Park \& Nuntrakune, 2013).

The existing theoretical points of view on STEM in the system of higher education, in our opinion, do not embrace the range of problems completely, which significantly reduces the effectiveness of the practical activity. Science in STEM refers to both natural sciences like physics, chemistry or biology and formal sciences like mathematics or statistics. Some researchers include STEM and psychology, but this point of view is debatable. The key skill that helps develop STEM learning is the ability to use correctly the found information and apply it successfully in practice. Consequently, it seems obvious that at present the content of this concept is shifting into the plane of real practical activity, having influence on all levels of education: general education, vocational education, and additional education (Hassan et al., 2019; Kelley \& Knowles, 2016; Nepeina et al., 2020).

Modern STEM education is a combination of sciences, which is directed at developing new technologies, at introducing innovations, the basis of which is the training of engineering personnel. It is important to note that such an education system based on STEM will be effective only if it is properly managed, and its stable operation at all levels will be observed (Chanthala et al., 2018; Gatan et al., 2021; Goates et al., 2016; Menger, 2014; Parks et al., 2021; Raven, 2002; Segura, 2017; Shchedrovitsky, 1995; Shchedrovitsky et al., 1993; Skurikhina et al., 2018; Starcic et al., 2017; Valeeva \& Valeeva, 2013).

\section{MATERIALS AND METHODS}

In this paper, the authors want to touch upon a comprehensive theoretical and methodological study conducted on the declared problem to identify the problem of the formation and development of the STEAM approach in the education system in the Russian Federation at all levels: general education, vocational education, and additional education.

A comprehensive theoretical and methodological study was aimed at solving the problem of defining the structure and content of the concept of "STEM education", substantiating its importance, prerequisites for formation and development trajectories.

The object of this study was STEM education. The subject of this research was the STEM approach and STEM technologies in the system of general education, vocational education, and additional education.

The methodological foundation of the study was the general scientific propositions on the holistic, systemic, and dialectical approaches to research, which made it possible to assess the totality of interrelated and interacting elements that form a certain integrity. The use of these approaches provided a comprehensive analysis and formulation of the research problem and determined the strategy for its study.

The main principles of studying the stated problem were:

- the principle of ascent from the abstract to the concrete, which ensured the disclosure of the essence and obtaining a holistic image of the object under study;

- the principle of the unity of analysis and synthesis, which made it possible, by breaking down, to single out individual parts (structure) and interdisciplinary connections of the object under study and to realize it not as a separate element, but as part of a complex whole. Also, this principle made it possible to study the object under study in the unity and connection of all its parts and features;

- the principle of the logical and the historical, which provided the disclosure of specific conditions and forms of development of the studied object, the sequence of their transitions from historically necessary stages to others, as well as the disclosure of the role those individual elements of the studied object play in the developed whole;

- the principle of identifying different-quality connections and their interaction in the object, which made it possible at the system level to consider the object under study as a set of versatile and different-quality interaction to identify the place (role) of this object in a certain system of coordinates;

- the principle of synthesis of structural, functional, and genetic representations of an object, which ensured the study of the object of research from the standpoint of its origin, stages of existence, the sequence of changes and historical trends.

In a comprehensive theoretical and methodological study presented in the paper, a phenomenological analysis of the indicated problem was used.

The leading methods of scientific knowledge were (Bazhenova, 2015):

- the method of comparison, which allowed us to compare the elements of the object under study, to identify features of similarity and differences in its interpretation in different sciences. The result of this comparison was generalization - the combination of common features and properties in the concept of STEM education. Generalization manifested itself in joining the qualitative and quantitative characteristics of the concept. An essential condition for generalization was that the generalization of the content of the concept of STEM education was carried out not by its individual elements, but by the whole concept;

- abstraction as a research method was used by us to identify only signs, properties, characteristics in the concept of STEM-education, but not generic or specific concepts regarding the object under study. When using the abstraction method, the object under study was included in the diversity of connections and 
relationships. As the concept of STEM education was abstracted, particulars disappeared and essential features were clearly identified, the most important patterns and interrelationships emerged. As a result of abstraction, we managed to concretize the most complete knowledge about the concept of STEM education;

- content analysis, as a method of qualitative and quantitative examination of the content of documents to identify or measure social facts and trends reflected in these documents, allowed us to trace the necessary changes (primarily in the legislative documents of the Russian Federation) aimed at improving the conditions to manage STEM education;

- discursive analysis of the text, gave us an opportunity to carry out a qualitative and contentrelated analysis of the object of research, and to find not only clearly present and explicitly recorded text data, but also hidden, latent meanings of the message. The generalized model of qualitative content-based discourse analysis consisted of the following step-bystep research strategies: ascertainment of the material under study; highlighting its formal characteristics; designation of the context as a communication situation; choice of direction and strategy of analysis; theoretical differentiation and structuring of research stages; determination of techniques and means of analysis when using a specific research model; definitions of units of analysis; checking the system of categories in theory and on empirical material; implementation of description, reconstruction, interpretation; collection of research results, their generalization, interpretation and structuring (Mitina \& Evdokimenko, 2010);

- theoretical analysis gave us an opportunity to carry out the study of domestic and foreign literature on the stated problem, to analyze the accumulated empirical experience on the problem, and analyze the existing concepts and approaches to the study of the stated problem at the theoretical level.

\section{RESULTS}

The President of the Russian Federation in his Address to the Federal Assembly (back in 2014), for the first time pointed out the need to bring engineering education in the country up to world standards. Robotic complexes became the priority areas of the development of science and technology in Russia, and soon a network of engineering and technical centers began to spring up: quantifiers, wooden blocks in universities, centers of the Center for Computer and Information Technologies and Sirius. Special classrooms began to sprout in schools, which are equipped with everything for creating programmable robots. The basis for the development of an innovative economy in our country began to be created, which requires serious changes in the education system.
Today, more and more STEM centers are opening in technology parks, universities, or as part of Educational Technology Support Centers, which help high school students master new technologies and motivate them to further study science and technology (Hashemi et al., 2015).

Master's courses in training STEM teachers began to be provided in Russian universities, and the practice of using the STEM approach in additional education and the segment of paid educational services is rapidly expanding.

Students are willing to work in teams, they experiment, do research, design, and assemble robots, and create websites.

Over the past few years, intellectual-related creative industries have become increasingly important in the innovation economy. Creative industries serve as a force propelling the global economy towards growth, and youth employment in creative industries is already higher than in the real sector.

These changes pose new challenges to the education system of our country, namely: the need for a wider inclusion of creative disciplines in the curriculum.

In the United States of America, where more than thirty million jobs have been created in the creative industries, this demand has transformed the concept of STEM: a fifth component, Art, was added to the synthesis of science, technology, engineering, and mathematics. As a result, a new abbreviation and concept appeared - STEAM. Thus, the concept of STEM is gradually transformed into a broader concept of STEAM. The ideologues behind the STEAM approach were inspired by the examples of great scientists who combined scientific efforts with creativity and, through advanced non-linear thinking and imagination, were able to bring about a revolution in the world. The STEAM approach will continue to focus on project performance, practice orientation, and disciplines, but will change the coordination of key disciplines. At the level of curriculum development, for example at a university, STEAM includes not only STEM subjects in engineering and science, but also humanities and creative disciplines:

- literature,

- planning,

- architecture,

- music,

- pictorial art.

STEM subjects and technologies offer clear solutions to applied problems, and the humanities open a way out in a state of uncertainty, ambiguity, and volatility. Thus, schoolchildren and students learn to combine harmoniously scientific rigor and creative freedom in their work. From the point of view of the methodological level, the STEAM approach assumes that, in addition to 
solving technological issues during project activities, students will:

- acquire teamwork skills;

- learn to criticize and defend their opinion constructively;

- acquire performing skills;

- learn to generate ideas against lack of clarity;

- use marketing, advertising principles to ensure effective promotion, popularization of a particular product;

- understand the existing creative potential for the practical use of a particular technology in various fields of activity.

\section{The Following Reasons Can be Distinguished for the Priority of STEAM Training in Russian Federation}

1) In the near future, there will be an acute shortage of engineers, specialists in high-tech industries, etc. in the world, and therefore in Russia.

2) Since in the future mankind will need representatives of professions who will deal with areas where technology intersects with the natural sciences, it will be necessary to develop the field of education in the field of biotechnology, as well as nanotechnology.

3) Future specialists will need comprehensive training in various fields of knowledge.

The idea of uniting in a group seems valuable taking account of the peculiarities of the contemporary world, in which the value of the ability to interact, to cooperate, and not just rely on one's own strengths has increased significantly in solving a problem.

An idea is a goal, and each goal, as everybody knows, is achieved by solving the problems which it consists of.

\section{We Can Formulate the Following Tasks of STEAM - Education in Russia:}

- developing a tool or method to create a unified educational space in which students can find or create points of contact with their temperament, mentality, and skills.

- creating conditions in which this tool $=$ method will work not situationally, here, and now, but in time, for a long time and even in conditions of continuity, that is, in the system from general education to vocational education, as well as additional education (Zakolodezhnaya, 2020).

- integrating STEM and STEAM - training in the practice of existing research centers, technology parks, for example, the Skolkovo innovation center.

- increasing STEM literacy of society, widespread retraining, professional development courses, which will help any specialist to remain in demand in the highly skilled labor market even in those conditions when previously acquired professions are unnecessary in modern society.

Summing up, we note that such an approach teaches us to consider problems as the whole thing, and not in the context of one area of science or technology. In our opinion, STEAM will contribute to the development of such important attributes and skills as:

- a comprehensive understanding of the problems;

- creative thinking;

- engineering approach;

- critical thinking;

- understanding and applying the scientific method;

- understanding of the basics of design.

The following STEAM teaching methodology can be proposed:

- mixed learning environment;

- the methods must be applicable in daily life;

- STEAM must be one of the areas of project implementation;

- availability of educational and research activities at school and outside;

- the curriculum should be based on the idea of using learning;

- mandatory interdisciplinary and applied approach;

- STEAM should combine 5 separate disciplines into a single training system.

Today, in many countries of Europe and Asia, active research is being carried out in the field of practical operation of the elements of STEAM education. Research shows that there is a huge number of variations in the practical implementation of STEAM elements in certain components of the educational process (Savinova \& Shubnyakova, 2015).

STEAM education has already been introduced in one form or another into the education systems of such countries as the United States of America, Vietnam, Hong Kong, Qatar, Turkey, and Canada (Loyalka et al., 2021; Ma, 2021). For example, acoustics can act as a connecting element for children of preschool age. The researchers believe that acoustics are ideally suited for this educational technology because it has a close relationship with music. However, to achieve the required pedagogical, educational, and developmental effect, teachers will need extensive experience, skills, and knowledge (Alsmadi, 2020).

STEAM can also successfully incorporate the growing interest in physical phenomena among primary school students. For example, the Scientists for tomorrow initiative was supported in Chicago. This program implies the opportunity for students to 
familiarize themselves with a variety of scientific educational courses covering various topics.

Substantial STEM training can be received through corporate educational programs at technical universities. These are joint programs of the university and an industrial partner. The partner pays tuition for students, helps to draw up the curriculum and select candidates. At the same time, students work on a graduation project with an industrial partner, solving a real technological problem of the company. For example, Hong Kong University of Science and Technology (HKUST) integrates a program of three faculties of the university: science, engineering, and business management with the support of a technology company (Nepeina et al., 2020).

In our country, this problem has also acquired great importance, therefore, it needs to be resolved. Currently, active work is underway to open special CTPE centers. They do part-time work to increase student involvement in robotics and engineering. Also, active work is being carried out to attract representatives of domestic business to the education development system, which brings a noticeable positive effect.

STEM education helps prepare valuable people for full-time jobs in technology companies immediately after graduation. In most developed countries, secondary school teachers take courses where they learn how to use a variety of interdisciplinary strategies in their own work. As practical results show, thanks to the use of STEAM technologies in the course of studying the school program of physics and mathematics, a noticeable increase in the level of academic performance among high school students, university students are achieved, along with the development of their basic creative skills and abilities (Konyushenko et al., 2018).

This fact indicates that the introduction of such a technology is possible in various educational areas in our country. At the same time, such a step helps to achieve a noticeable improvement in the main indicators of the effectiveness of educational activities. Russia's aspiration to become one of the most developed countries in the world requires that society should make efforts to increase student interest in scientific knowledge, research, and technology.

STEM aims to foster the development of skills of the $21^{\text {st }}$ century:

- knowledge, identification, recognition and classification of the content of the subject;

- modeling and simulation;

- preparation of design and experimental work;

- relocation, redesign;

- ingenuity and creativity;

- theorizing, criticism, substantiation.
The following skills of the $21^{\text {st }}$ century are distinguished: critical thinking, collaboration and teamwork, defining concepts in context, explaining concepts, self-organizing, self-exploration, and using known facts. STEM is quality education, an important part of the modern education system (Nechitailo \& Makeyev, 2018).

It is difficult for teachers to understand STEM education because they do not know the purpose of the STEM approach and its suitability for use in student educational activities. We consider it appropriate to quote the words of J. Dewey: "If we teach today as we taught yesterday, we will steal tomorrow from our children." Consequently, STEM education should become a trend in modern education with great and wide opportunities for a thinking teacher in terms of the student's personal growth. STEM education includes experimentation, conversation, comparison, reasoning, and conclusions. It is important to note that teachers alone will not be able to become STEM teachers, which requires the introduction of a special discipline in STEM teaching or professional development in pedagogical universities. The systems of general education, vocational education and additional education should not exist in isolation, they should be incorporated into a single educational environment, for which STEM education should be the foundation.

\section{DISCUSSION}

Achieving a breakthrough in the scientific, technical, and socio-economic development of our country includes ensuring Russia's entry into the five largest economies of the world.

STEM technologies have been actively used in learning for a long time in schools in the USA, Europe, and other developed countries. In Russia, this process is just making a start.

Thus, we can link the achievement of economic growth in our country with the widespread introduction of STEM-based approaches into educational programs.

According to the data provided by RBC, the demand for STEM education in Russia is also growing. The Russian labor market needs 222 thousand workers in the field of digital technologies. Their number will have grown to 300 thousand people by 2024 .

To this end, the Russian Federation faces the task of achieving impressive results in education to enter the ten leading countries in the world in terms of the quality of general education. One of the main criteria for assessing the quality of general education in Russia is the educational result in the international document "Skills for the $21^{\text {st }}$ century."

At present, the most popular skills can be conditionally divided into three main groups: 
1) cognitive, among which the main ones should be considered those that are responsible for all kinds of processes of cognition, knowledge, as well as the development of creative potential;

2) internal personal, consisting of the openness of the intellectual order, work ethics, personal self-confidence;

3) interpersonal, which determine whether a person has teamwork skills, the ability to work in a group and effectively interact with other people.

All listed skills should be shaped up in the process of the student's learning in the framework of the STEM and STEAM approaches in education. However, the question arises: How is this goal being realized in our country? To answer this question, we analyzed the number of students enrolled in STEM and STEAM education programs in Russia. To calculate this indicator, we collected the data on the basis of reports provided by the Ministry of Science and Higher Education of the Russian Federation (using federal statistical observation forms No. HPE-1), which are available in the public domain. (Ministry of education and science of the Russian Federation, 2021). The STEM Degree List, approved by the US Department of Homeland Security in 2010, was taken as the basis for determining the required qualifications (STEM Degree-List, 2021). CIP (Classification of Instructional Programs) codes were transferred into specialty codes by order of the Ministry of Education and Science of Russia (Order of the Ministry of Education and Science of the Russian Federation, September 12, 2013, No. 1061) but taking account of the specifics of two different classifiers of higher professional education programs in Russia and the USA. As a result, the following areas of knowledge were included: mathematics and technical sciences, engineering, technology, art and culture. In total, 113 programs (Semenova, 2019a, 2019b, 2019c) were selected within the framework of the bachelor, specialist, and master courses, which form the main STEAM list (Table $1)$.

Thus, the share of STEAM-students in Russia can be determined using the following formula:

$$
\begin{aligned}
& \text { STEAM } M_{\text {students }} \\
& =\frac{S T E A M_{b a c}+S T E A M_{\text {mag }}+S T E A M_{\text {spec }}}{B A C+M A G+S P E C} * 100
\end{aligned}
$$

The numerator of the formula includes the total number of students enrolled in the designated STEAM areas of training on higher professional education programs (bachelor's, master's, specialist's). The denominator includes the total number of students enrolled in higher professional education programs (bachelor's, master's, specialist's).

\begin{tabular}{|c|c|c|}
\hline № & Training areas in higher education program in the field of IT & Degree \\
\hline & Bachelor programs & \\
\hline 1 & Applied mathematics and information science & Bachelor \\
\hline 2 & Mathematics and computer sciences & \\
\hline 3 & Fundamental informatics and information technologies & \\
\hline 4 & Software and administration of information systems & \\
\hline 5 & Informatics and computer engineering & \\
\hline 6 & Information systems and technologies & \\
\hline 8 & Software engineering & \\
\hline 9 & Information security & \\
\hline 10 & Radio engineering & \\
\hline 11 & Infocommunication technologies and communication systems & \\
\hline 12 & Electronic design and technology & \\
\hline \multirow[t]{2}{*}{13} & Electronics and nanoelectronics & \\
\hline & Specialist programs & \\
\hline 16 & Information security of automated systems & \\
\hline 17 & Information and analytical security systems & \\
\hline 18 & Information technology security in law enforcement & \\
\hline 19 & Radio electronic systems and complexes & Engineer \\
\hline \multirow[t]{2}{*}{20} & Special radio engineering systems & Engineer of special radio engineering systems \\
\hline & Master programs & \\
\hline 21 & Applied mathematics and information science & Master \\
\hline 22 & Mathematics and computer sciences & \\
\hline 23 & Fundamental informatics and information technologies & \\
\hline 24 & Software and administration of information systems & \\
\hline 25 & Informatics and computer engineering & \\
\hline 26 & Information systems and technologies & \\
\hline 27 & Applied information science & \\
\hline 28 & Software engineering & \\
\hline 29 & Information Security & \\
\hline 32 & Electronic design and technology & \\
\hline 33 & Electronics and nanoelectronics & \\
\hline
\end{tabular}

Table 1. List of STEAM courses in bachelor, master, and specialist programs in Russia 
Table 1 (continued). List of STEAM courses in bachelor, master, and specialist programs in Russia

\begin{tabular}{|c|c|c|}
\hline № & Training areas in higher education program in the field of Robotics & Degree \\
\hline & Bachelor programs & \\
\hline 34 & Applied mathematics and information science & Bachelor \\
\hline 35 & Mathematics and computer sciences & \\
\hline 36 & Fundamental informatics and information technologies & \\
\hline 37 & Software and administration of information systems & \\
\hline 38 & Informatics and computer engineering & \\
\hline 39 & Information systems and technologies & \\
\hline 41 & Software engineering & \\
\hline 42 & Information security & \\
\hline 43 & Radio engineering & \\
\hline 44 & Infocommunication technologies and communication systems & \\
\hline 45 & Electronic design and technology & \\
\hline \multirow[t]{2}{*}{46} & Electronics and nanoelectronics & \\
\hline & Specialist programs & \\
\hline$\overline{47}$ & Computer security & Information protection specialist \\
\hline 49 & Information security of automated systems & \\
\hline 50 & Information and analytical security systems & \\
\hline 51 & Information technology security in law enforcement & \\
\hline 52 & Radio electronic systems and complexes & Engineer \\
\hline \multirow[t]{2}{*}{53} & Special radio engineering systems & Engineer of special radio engineering systems \\
\hline & Master programs & \\
\hline 54 & Applied mathematics and information science & Master \\
\hline 55 & Mathematics and computer sciences & \\
\hline 56 & Fundamental informatics and information technologies & \\
\hline 57 & Software and administration of information systems & \\
\hline 58 & Informatics and computer engineering & \\
\hline 59 & Information systems and technologies & \\
\hline 60 & Applied information science & \\
\hline 61 & Software engineering & \\
\hline 62 & Information Security & \\
\hline 65 & Electronic design and technology & \\
\hline 66 & Electronics and nanoelectronics & \\
\hline \multirow[t]{2}{*}{ № } & Training areas in higher education program in the field of Arts & Degree \\
\hline & Bachelor programs & \\
\hline
\end{tabular}

67 Journalism $\quad$ Bachelor

68 Television

69 Media-communication

70 Intelligent systems in the humanitarian sphere

71 Fine arts

72 Directing theatricals and festivals

73 Choreographic performance

74 Musicology and Applied Art

75 Design Specialist programs

$76 \quad$ Translation and translation studies

77 Sound engineering for cultural performances and concert programs

Literature creativity

Art of concert performance

Artistic direction of the Opera and Symphony Orchestra and Academic Choir

Musical sound engineering

Musical and theatrical art

Musicology

Composition

Conducting a military wind band

Painting and fine arts

87 Directing in film making and television

88 Sound engineering for audio-visual arts

89 Photography in film making

90 Production

91 Cinematography

Musicologist. Teacher. Music journalist. Media editor, etc.

Bachelor

Linguist-translator

Sound engineer

Literary worker, translator of literature

Teacher

Military Band Conductor

Specialist. Painter

Director of fiction / non-fiction films and television

films. Director of animation and computer graphics, etc.

Sound engineer

Cameraman. Camera operator. Teacher

Film and TV Producer; Producer of radio programs.

Multimedia producer, etc.;

Film critic 
Table 1 (continued). List of STEAM courses in bachelor, master, and specialist programs in Russia

\begin{tabular}{lll}
\hline Master programs & Master \\
\hline 92 & Journalism \\
93 & Television \\
94 & Media communication \\
95 & Philology \\
96 & Linguistics \\
97 & Fundamental and applied linguistics \\
98 & Intelligent systems in the humanitarian sphere \\
99 & Arts and humanities \\
100 & Fine arts \\
101 & Culturology \\
102 & Folk art culture \\
103 & Directing theatricals and festivals \\
104 & Choreographic art \\
105 & Dramaturgy \\
106 & Theatrics \\
107 & Musical and instrumental art \\
108 & Vocal art \\
109 & Art of folk singing \\
110 & Conducting \\
111 & Art \\
112 & Musicology and Applied Art \\
113 & Design
\end{tabular}

Table 2. Summary data on the number of students enrolled in STEAM areas of training

\begin{tabular}{|c|c|c|}
\hline № & Enrollment indices on HPE programs in Russia & $\begin{array}{c}\text { Number of } \\
\text { students (people) }\end{array}$ \\
\hline 1 & $\begin{array}{l}\text { Total number of students enrolled in higher professional education programs (HPE) (bachelor's, specialist's, master's } \\
\text { degree), people. }\end{array}$ & 4049333 \\
\hline 2 & $\begin{array}{l}\text { Total number of students enrolled in STEAM training in higher professional education programs (bachelor's, } \\
\text { specialist's, master's), people. }\end{array}$ & 816940 \\
\hline 3 & Of them: & \\
\hline 4 & studying in the IT area on HPE programs ("IT"), people. & 341401 \\
\hline 5 & studying in the humanities on HPE programs ("Art"), people. & 207141 \\
\hline 6 & studying in the area of "Robotics" (Automation and control) (Robotics), people. & 268398 \\
\hline 7 & $\begin{array}{l}\text { The proportion of students in STEAM courses to the total number of students enrolled in the university training } \\
\text { program (the total number of students in all HPE programs), \% }\end{array}$ & 20,2 \\
\hline 8 & $\begin{array}{l}\text { Proportion of IT courses to the total number of students studying on HPE programs (number of students in all the } \\
\text { courses of HPE), \% }\end{array}$ & 8,5 \\
\hline 9 & Proportion of IT courses to the total number of STEAM-education (the share of IT in STEAM), \% & 42 \\
\hline 10 & $\begin{array}{l}\text { Proportion of the humanities courses ("Arts") to the total number of students studying on HPE programs (number of } \\
\text { students in all the courses of HPE), \% }\end{array}$ & 5,1 \\
\hline 11 & $\begin{array}{l}\text { Proportion of the humanities courses ("Arts") to the total number of students in STEAM-education (the share of } \\
\text { "Arts" in STEAM), \% }\end{array}$ & 25 \\
\hline 12 & $\begin{array}{l}\text { Proportion of the courses in Robotics to the total number of students studying on HPE programs (number of students } \\
\text { in the courses of HPE), \% }\end{array}$ & 6,6 \\
\hline 13 & $\begin{array}{l}\text { Proportion of courses in Robotics to the total number of students in STEAM-education (the share of Robotics in } \\
\text { STEAM), \% }\end{array}$ & 33 \\
\hline
\end{tabular}

The group of IT courses, the group "Robotics" and the group of courses in the humanities ("Art") were singled out by Semyonova et al. (2020) within the framework of their research "STEAM-education and ITemployment as factors of adaptation to the digital transformation of the economy in the regions of Russia" (Table 1).

Data were collected for 85 territorial entities of the Russian Federation. The data source was the Ministry of Education and Science of the Russian Federation (2021) and Rosstat (2021). Table 2 presents our statistical estimates of the number of students in Russia in general of $02 / 01 / 2021$.

To illustrate the data, diagrams of the distribution of students according to STEAM-areas in programs of higher professional education were created (Figures 1-3).
Thus, from Table 2, we can see that more than half a million people study in STEAM training areas in higher professional education programs in Russia, which is $20.2 \%$ of the total number of students in the country. However, the share of each STEAM area in the total number of HPE students in the context of the development of "Industry 4.0 " is rather low (Figure 2).

Nevertheless, it should be noted that recently there has been an increase in specific indicators of SREAM education in our country. Thus, the study undertaken by Semyonova et al. (2020), showed that in 2018 "an aggregate of the three priority areas for training specialists "IT", "Robotics", and "Art" ", accounted for only $8 \%$ of the total personnel potential of the country, (about 15\% of the general training of highly qualified personnel on HPE programs). Whereas at present the three STEAM areas have increased overall by $5.2 \%$. 


\section{Proportion of students studying on a higher education program}

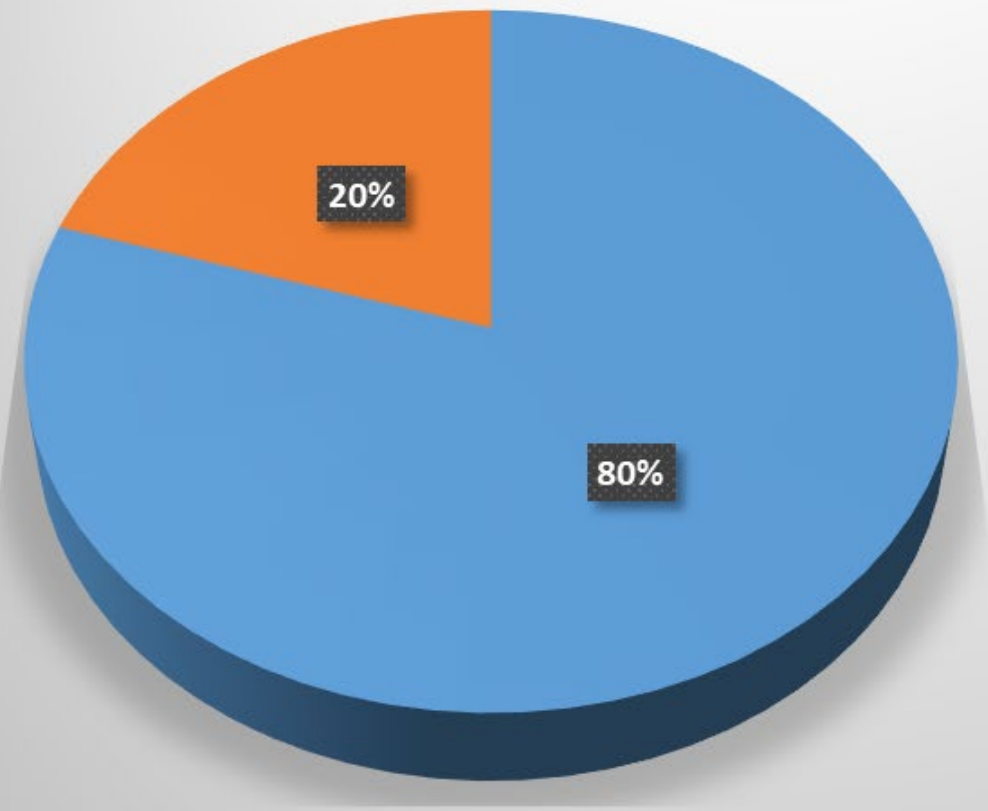

Proportion of students studying on higher education programs outside STEAM-courses (to the total number of students)

- Proportion of students in STEAMcourses to the the total number of students studying on a higher education program

Figure 1. The proportion of students enrolled in the programs of higher professional education (\%)

\section{Proportion of students of STEAM-programs to the total number of students in HPE}

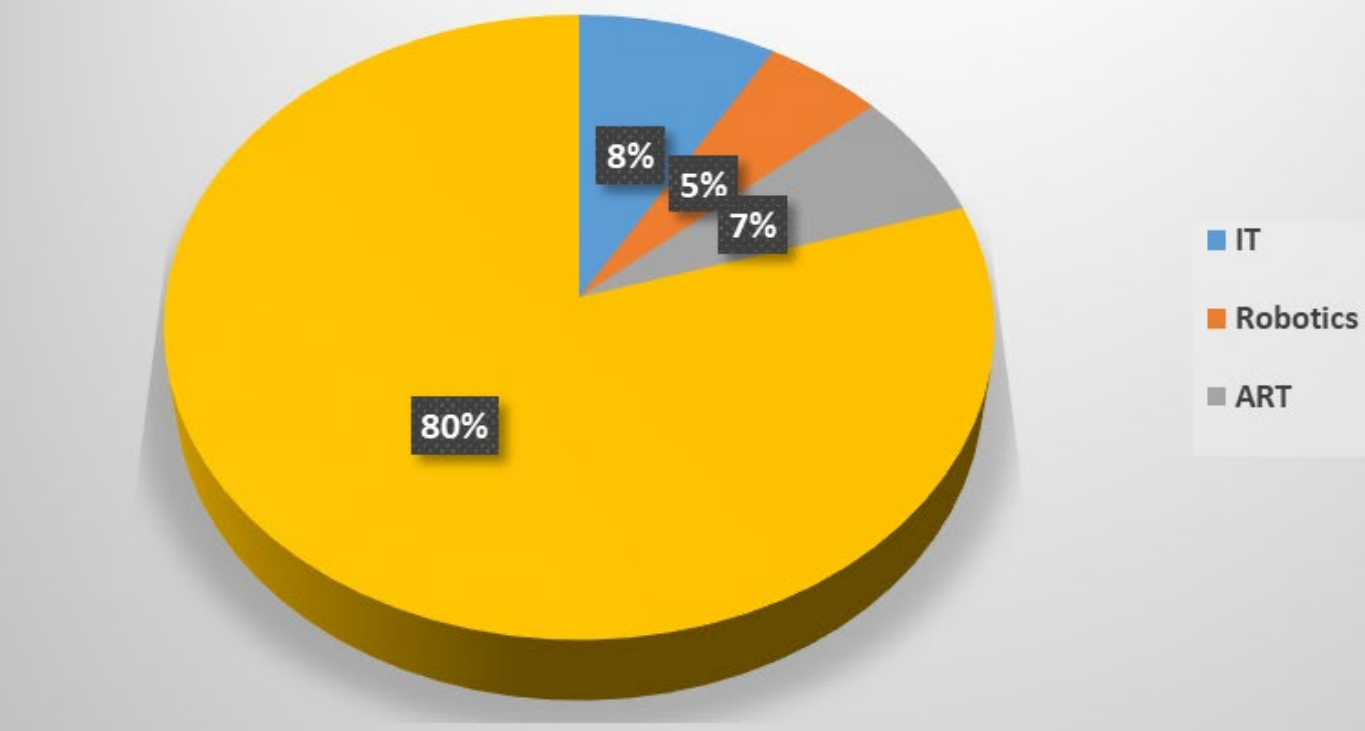

Figure 2. The proportion of students in STEAM programs to the total number of students enrolled in university programs $(\%)$ 


\section{Proportion of students in STEAM-courses by training areas}

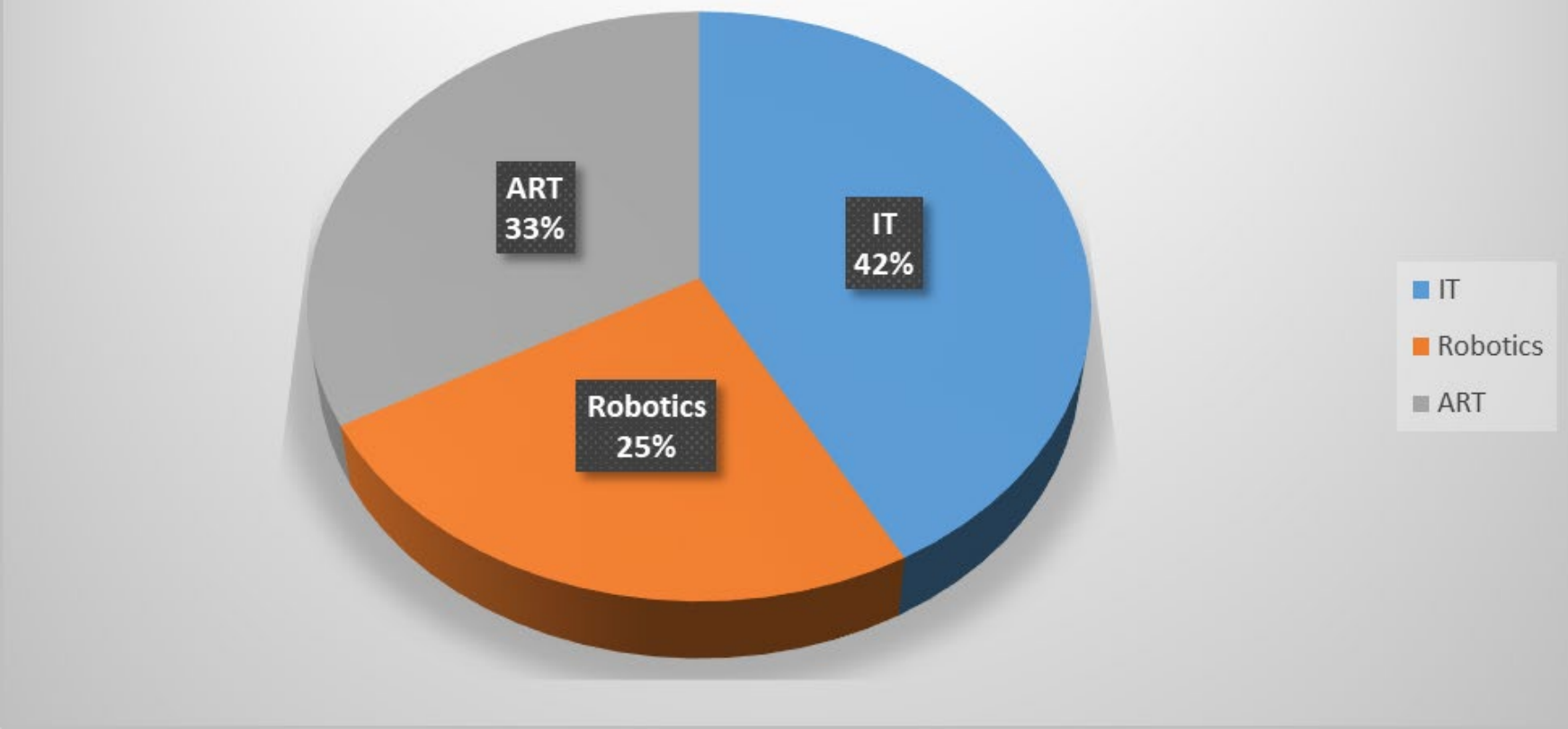

Figure 3. The proportion of students in STEAM courses by areas of training (\%)

Thus, the analysis of the current state of STEM and STEAM education in higher education in the Russian Federation suggests that it is necessary to stimulate the development of information and communication technologies in the country's education system in general, as well as to develop comprehensive programs for adapting STEM and STEAM approaches among the subjects of educational relations.

In the context of modern global risks and challenges, the educational trajectory of development in Russia should be conceptually consistent with the new strategy in the field of natural science education adopted in the United States, "The Path to Success: American Strategy for STEM Education" (STEM-strategy, 2018: "Charting a course for success: America's strategy for STEM education»). Experts believe that through the practical implementation of STEM and STEAM technologies, it is possible to improve the efficiency of the quality of training for the purposes of the modern digital economic sphere. In this regard, the primary competences obtained in the higher education system in the areas of STEM and STEAM training should be cognitive, personal, and interpersonal competences, expressed in digital literacy, computational thinking, creativity, open mind, soft skills, and others. The concept of STEAM education in the system of higher professional education in Russia will ensure the transformation of ideas about scientific knowledge and build an innovative development process through the formation of skills in the field of exact sciences, linguistics, engineering, art, etc.

\section{CONCLUSION}

The STEM education system has such a structure that gives students an opportunity to use their theoretical knowledge in practice. They can apply it in the implementation of a wide variety of activities. At the same time, they perform conscious actions and deeds (Caplan, 2017).

Experts rightly point out that school knowledge cannot be sufficient for children to realize themselves successfully in the professional sphere. All this explains the need to introduce the humanities into the STEM system, which makes it possible to achieve a significant expansion, enrichment of the creative component of educational activities. The introduction of disciplines related to the humanities allowed the formation of such a field as "STEA-education", which is, in fact, a further development of the STEM system.

In general, scientists believe that STEAM is a model of training designed to develop creativity, critical thinking, and other creative skills. However, reliable empirical research are needed to explain the importance of introducing the components of art and creative education into the structure of both mathematical and technological training of future specialists who will work in the modern digital economic environment.

We believe it is important to apply elements of arts education in teaching mathematics, science, and engineering, as this will allow us to improve students' verbal and non-verbal skills, develop their critical 
thinking, and teach them to be open to the perception of other people. Teachers, on the other hand, must understand the sociocultural situation, in other words, develop social emotional meaning. This is especially necessary for future teachers of mathematics, physics, chemistry, computer science, technology (Sabirova \& Deryagin, 2018).

Design, as well as all kinds of research technologies should be a compulsory component of the educational process of future teachers. All this will help teachers to develop the required skills associated with the formation, as well as the implementation of effective management of project, creative, experimental activities of students.

Even now, one can start the process of organizing and implementing special courses to improve the qualifications of teachers to receive STEM and STEAM education. Provided that our education system can provide admission not only for students majoring in a certain subject, but also for teachers from other fields of knowledge to receive training in educational institutions that design quality, practice-oriented programs and offer training and retraining courses of specialists. This means that it is important to form pedagogical training in a certain way to implement ideas that give the possibility of a comprehensive update of the content of the system for preparing students for subsequent successful life, as well as for the implementation of creative activity. Such training should unite both students and teachers, designers, managers, psychologists. That is, it is necessary to create an integral, unified system, where STEM and STEAM will be at the core.

Future economic growth will be determined by the availability of qualified personnel. The process of their formation should start at school, and after that the developmental work should continue by supporting and actively introducing STEAM teaching in colleges and universities. It is important that support and assistance should be provided through targeted development programs. They should be based on the active participation of students, as well as their mentors, in specific project work in the presence of a space that has a pronounced creative character.

Project-based activities within the systems of formal as well as non-formal education make it possible for each participant to ensure the development of skills, as well as certain competencies that every person should possess in conditions of the modern digital age.

Author contributions: All authors have sufficiently contributed to the study, and agreed with the results and conclusions.

Funding: No funding source is reported for this study.

Declaration of interest: No conflict of interest is declared by authors.

\section{REFERENCES}

Akiri, E., Tor, H. M., \& Dori, Y. J. (2021). Teaching and assessment methods: STEM teachers' perceptions and implementation. Eurasia Journal of Mathematics, Science and Technology Education, 17(6), em1969. https:/ / doi.org/10.29333/ ejmste/10882

Aleksankov, A. M. (2017). The fourth industrial revolution and modernization of education: international experience. Strategic Priorities, 1(13), 53-69.

Alsmadi, M. A. (2020). Requirements for application of the STEM approach as perceived by science, math and computer teachers and their attitudes towards it. Eurasia Journal of Mathematics, Science and Technology Education, 16(9), em1879. https://doi.org/10.29333/ejmste/8391

Bahrum, S., \& Wahid, N., \& Ibrahim, N. (2017). Integration of STEM education in Malaysia and why to STEAM. International Journal of Academic Research in Business and Social Sciences, 7. https:/ / doi.org/10.6007/IJARBSS/v7-i6/3027

Bazhenova, Yu. A. (2015). Concerning generalization as a method of learning of the communication culture concept in the education science. Theory and Practice of Social Development, 3, 181-183.

Caplan, M. (2017). Scientists for tomorrow - A selfsustained initiative to promote STEM in out-ofschool time frameworks in under-served community-based organizations: Evaluation and lessons learned. ASEE Annual Conference and Exposition (pp. 12-15). Columbus.

Chanthala, C. \& Santiboon, T., \& Ponkham, K. (2018). Instructional designing the STEM education model for fostering creative thinking abilities in physics laboratory environment classes. AIP Conference Proceedings, 1923(1), 030010. https://doi.org/ $10.1063 / 1.5019501$

Frolov, A. V. (2010). The role of STEM education in the "new economy" of the USA. Issues of New Economy, 4(16), 80-90.

Frumin, I. D., Dobryakova, M. S., Barannikov, K. A., \& Remorenko, I. M. (2018). Universal competences and new literacy: what to teach today for tomorrow's success. Preliminary conclusions of the international report on trends in the transformation of school education. National Research University Higher School of Economics.

Gatan, P. R. G., Yangco, R., \& Monterola, S. L. (2021). Relationships among environmental literacy, locus of control, and future orientation of STEM students in the Philippines. Interdisciplinary Journal of Environmental and Science Education, 17(4), e2250. https:// doi.org/10.21601/ijese/10984 
Goates, C. B., Whiting, J. K., Berardi, M. L., Gee, K., \& Neilsen, T. (2016). The sound of STEAM: Acoustics as the bridge between the arts and STEM. Acoustical Society of America. https://doi.org/10.1121/ 1.4950007

Hashemi, N., Abu, M., Kashefi, H., Mokhtar, M., \& Rahimi, K. (2015). Designing learning strategy to improve undergraduate students' problem solving in derivatives and integrals: A conceptual framework. Eurasia Journal of Mathematics, Science and Technology Education, 11(2), 227-238. https:/ / doi.org/10.12973/eurasia.2015.1318a

Hassan, M. N., Abdullah, A. H., Ismail, N., Suhud, S. N. A., \& Hamzah, M. H. (2019). Mathematics curriculum framework for early childhood education based on Science, Technology, Engineering and Mathematics (STEM). International Electronic Journal of Mathematics Education, 14(1), 1531. https:/ / doi.org/10.12973/iejme/3960

Hymes, D. H. (1972). On communicative competence. In J. B. Pride \& J. Holmes (Eds.), Sociolinguistics. Selected readings (pp. 269-293). Penguin.

Kalugina, O. A., Vasbieva, D. G., Shaidullina, A. R., Sokolova, N. L., \& Grudtsina, L. Y. (2018). ESP blended learning based on the use of smart coursebook. XLinguae, 11(2), 445-454. https:/ / doi.org/10.18355/XL.2018.11.02.36

Kelley, T. R., \& Knowles, J. G. (2016). A conceptual framework for integrated STEM education. Internation Journal of STEM Education, 3, 11. https: / / doi.org/10.1186/s40594-016-0046-Z

Konyushenko, S. M., Zhukov, M. S., \& Moshev, E. A. (2018). STEM vs STEAM - education: a change in understanding how to teach. Bulletin of the Baltic State Academy of Fishing Fleet: Psychological and Pedagogical Sciences, 2(44), 99-103.

Kvachev, V. G., \& Yudina, M. A. (2017). Industry 4.0: Job failure or creative labor victory? Public administration. Electronic Bulletin, 64, 140-158.

Kvon, G. M., Vaks, V. B., Kalimullin, A. M., Bayanova, A. R., Shaidullina, A. R., Dolzhikova, A. V., \& Lapidus, N. I. (2019). Developing the informational and digital environment of a university: Problem analysis and assessment. Eurasia Journal of Mathematics, Science and Technology Education, 15(10), em1767. https:/ / doi.org/10.29333/ejmste/ 109503

Loyalka, P., Liu, O. L., \& Li, G. (2021). Skill levels and gains in university STEM education in China, India, Russia and the United States. Nature Human Behaviour, 5, 892-904. https://doi.org/10.1038/ s41562-021-01062-3

Ma, Y. (2021). Reconceptualizing STEM education in China as Praxis: A curriculum turn. Sustainability,
13(9), 4961-4973. https://doi.org/10.3390/ su13094961

Menger, K. (2014). Research on the methods of the social sciences and political economy in particular. DirectMedia. https://biblioclub.ru/index.php?page= book\&id=26826

Ministry of Education and Science of the Russian Federation. (2021). https://www.minobrnauki. gov.ru/ru/activity/act/dmaip/stat/svedu

Mitina, O. V., \& Evdokimenko, A. S. (2010). Methods of analysis of text: methodological foundations and software implementation. Bulletin of the South Ural State University. Series: Psychology, 40(216), 29-38.

Nechitailo, A. N., \& Makeyev, A. A. (2018). The principle of duality of consciousness and its consideration in modern technologies of teaching the course of general physics. World of science, culture, education, 1(68), 79-80.

Nepeina, K., Istomina, N., \& Bykova, O. (2020). The Role of Field Training in STEM Education: Theoretical and Practical Limitations of Scalability. European Journal of Investigation in Health, Psychology and Education, 10(1), 511-529. https:/ / doi.org/10.3390/ ejihpe10010037

Order of the Ministry of Education and Science of the Russian Federation. (2013). On approval of lists of special areas and directions of preparation of higher education. https:/ / base.garant.ru/70480868

Park, J.-Y., \& Nuntrakune, T. (2013). A conceptual framework for the cultural integration of cooperative learning: A Thai primary mathematics education perspective. Eurasia Journal of Mathematics, Science E Technology Education, 9(3), 247-258.

https:/ / doi.org/10.12973/eurasia.2013.933a

Parks, M. B., Hendryx, E. P., \& Taylor, A. T. (2021). The Study of Stream Litter Accumulation as a Model for Cross-Disciplinary, Transformative, Affordable, and Scalable Undergraduate Research Experiences in STEM. Interdisciplinary Journal of Environmental and Science Education, 17(3), e2245. https:/ / doi.org/ $10.21601 /$ ijese/10935

Raven, J. (2002). Competence in modern society: its identification, development and release. Kogito-center.

Rosstat. (2021). https:/ / rosstat.gov.ru/databases

Sabirova, F. M., \& Deryagin A. V. (2018). The creation of junior schoolchildren's interest in the experimental study of physical phenomena using the elements of the technology of problem-based. International Journal of Engineering $\mathcal{E}$ Technology, 7(2), 150-154.

Salakhova, V. B., Bazhdanova, Y. V., Dugarova, T. T., Morozova, N. S., \& Simonova, M. M. (2020). The crisis of education in conditions of the covid-19 pandemic: The model of blended learning. Systematic Reviews in Pharmacy, 11(12), 1411-1416. 
Salakhova, V. B., Umerkaeva, S. S., Ignatyev, S. E., Nalichaeva, S. A., \& Zebnitskaya, A. K. (2019. Informational and psychological safety of the educational environment in forming a person's personality: Current challenges and risks (ecological and psychological approach). EurAsian Journal of BioSciences, 13(2), 1797-1803.

Savinova, S. Yu., \& Shubnyakova, N. G. (2015). Project activity in vocational training of bachelors majoring in management. Innovative Projects and Programs in Education, 5, 46-52.

Segura, W. A. (2017). The use of STEAM in higher education for high school teachers. Journal 21 World Multi-Conference on Systemics, Cybernetics and Informatics, Proceedings (WMSCI 2017), 1, 308-312.

Semenova, R. I. (2019a). Distribution of specialties (IT). https:/ / www.researchgate.net/publication/33689 0275_Raspredelenie_specialnostej_IT

Semenova, R. I. (2019b). Distribution of specialties (Robotics). https://www.researchgate.net/publica tion/336890089_Raspredelenie_specialnostej_Rob ototehnika

Semenova, R. I. (2019c). Distribution of specialties (Art). https://www.researchgate.net/publication/33689 0091_Raspredelenie_specialnostej_Art

Semenova, R. I., Zemtsov, S. P., \& Polyakova, P. N. (2019). STEAM-education and IT-employment as factors of adaptation to the digital transformation of the economy in the regions of Russia. Innovation, 11(253), 2-14.

Shchedrovitsky, G. P. (1995). The scheme of mental activity: System-structural framework, meaning, and content. Izbrannye trudy, 1, 281-298.

Shchedrovitsky, G. P., Rozin, V. M., Alekseev, N. G., \& Nepomnyashchaya, N. (1993). Pedagogy and Logic. Kastal.

Skurikhina, J. A., Valeeva, R. A., Khodakova, N. P., \& Maystrovich, E. V. (2018). Forming research competence and engineering thinking of school students by means of educational robotics. Eurasia Journal of Mathematics, Science and Technology Education, 14(12), em1639. https://doi.org/ 10.15293/2658-6762

Starcic, A. I., Huang, P. S., Valeeva, R. A., Latypova, L. A., \& Huang, Y. M. (2017). Digital storytelling and mobile learning: Potentials for internationalization of higher education curriculum. In T.-C. Huang, R. Lau, Y.-M. Huang, M. Spaniol, \& C.-H. Yuen (Eds.), Emerging technologies for education - 2nd International Symposium, SETE 2017, Held in Conjunction with ICWL 2017, Revised Selected Papers (pp. 400-406). Springer. https://doi.org/10.1007/978-3-31971084-6_45

STEM Degree-List. (2021). http:/ / stemdegreelist.com

STEM-strategy. (2018). Charting a course for success: America's strategy for STEM education. Office of Science and Technology Policy \& Policy. Committee on STEM Education. https://www. whitehouse.gov/wp-content/uploads/2018/12/ STEM-Education-Strategic-Plan-2018.pdf

Tugun, V., Bayanova, A. R., Erdyneeva, K. G., Mashkin, N. A., Sakhipova, Z. M., \& Zasova, L. V. (2020). The opinions of technology supported education of university students. International Journal of Emerging Technologies in Learning, 15(23), 4-14. https:// doi.org/10.3991/ijet.v15i23.18779

Usak, M., Masalimova, A. R., Cherdymova, E. I., \& Shaidullina, A. R. (2020). New playmaker in science education: COVID-19. Journal of Baltic Science Education, 19(2), 180-185. https://doi.org/10.33225 /jbse/20.19.180

Valeeva, L. A., \& Valeeva, R. A. (2013). Development of future engineers' critical thinking in foreign language teaching. 2013 International Conference on Interactive Collaborative Learning, ICL 2013, 438-439. https: / / doi.org/10.1109/ICL.2013.6644619

Zakolodezhnaya, L. L. (2020). Continuing education reading program. Foreign Languages at School, 2, 27 30.

\section{http://www.ejmste.com}

